\title{
Articles
}

\section{STRESS TESTING OF THE CZECH BANKING SECTOR}

\author{
Petr Jakubík, Jaroslav Heřmánek*
}

\begin{abstract}
:
The results of stress tests of the Czech banking sector based on credit risk and credit growth models, applied to the household and corporate sector are presented in the paper. The use of these newly developed models enables the stress tests to be linked to the CNB's official quarterly macroeconomic forecast. In addition, the article updates the stress scenarios, including simple sensitivity analyses of credit risk for individual sectors. Based on the analysis, an answer is sought to the question of whether the observed credit growth to corporate sector and households poses any threat to the stability of the banking sector. The analyses conclude that the banking sector as a whole seems to be resilient to the macroeconomic shocks under consideration.
\end{abstract}

Keywords: stress testing, financial stability, credit risk, credit growth, Czech banking sector JEL Classification: G21, G28, G33, G32, K20

\section{Introduction}

The creation of model scenarios and the stress testing methodology used in this article follows up on the previous method applied in the 2004 and 2005 Financial Stability Reports and published by Čihák, Heřmánek and Hlaváček (2007) and Jakubík (2007). The stress testing methodology is explained in CNB (2006). In these reports, the basic stress tests with historical scenarios were complemented by an interbank contagion test. The historical scenarios (described as Scenarios I and II) are based on extreme values from the past. Employed tests reflect the specific development of the Czech economy in 1997-1999. These tests were followed by model scenarios with in-built estimated macroeconomic factors from the CNB's quarterly forecast and estimated growth in non-performing loans (NPLs) from the macroeconomic credit risk model which is described in Jakubík (2007) in details.

* Petr Jakubík, Czech National Bank and the Institute of Economic Studies of Charles University in Prague (petr.jakubik@cnb.cz); Jaroslav Heřmánek, Czech National Bank (jaroslav.hermanek@cnb.cz). The findings, interpretations and conclusions expressed in this paper are entirely those of the authors and do not represent the views of any of the authors' institutions. Financial support from the IES (Institutional Research Framework 2005-2010, MSM0021620841) is gratefully acknowledged. 
The dynamic growth in the household credit market and the renewed growth in loans to non-financial corporations requires the previous tests of aggregate credit portfolios to be supplemented with credit growth models. The different growth rates of loans in these sectors are also leading to change in the structure of banks' loan portfolios. The different sensitivities of corporations and households to the macroeconomic environment along with the changing structure of the loan portfolio call for an extension of the credit risk model to include separate estimates for individual sectors. The estimated models of sectoral credit risk and credit growth serve for revision of the stress tests both for the aggregate loan portfolio and for the separate portfolios of the household and non-financial corporation sectors. The predictions obtained from the estimated models are used in simple tests of loan portfolios and in a stress test linked to the CNB's quarterly macroeconomic forecast.

This paper extends the stress testing framework elaborated by Čihák, Heřmánek and Hlaváček (2007) who employed only aggregate credit risk model estimated by Jakubík (2007). The incorporation of the newly developed credit growth and credit risk models into the existing stress testing methodology is described in Chart 1.

Chart 1

Architecture of Incorporation of Stress Tests with Consistent Model Scenarios

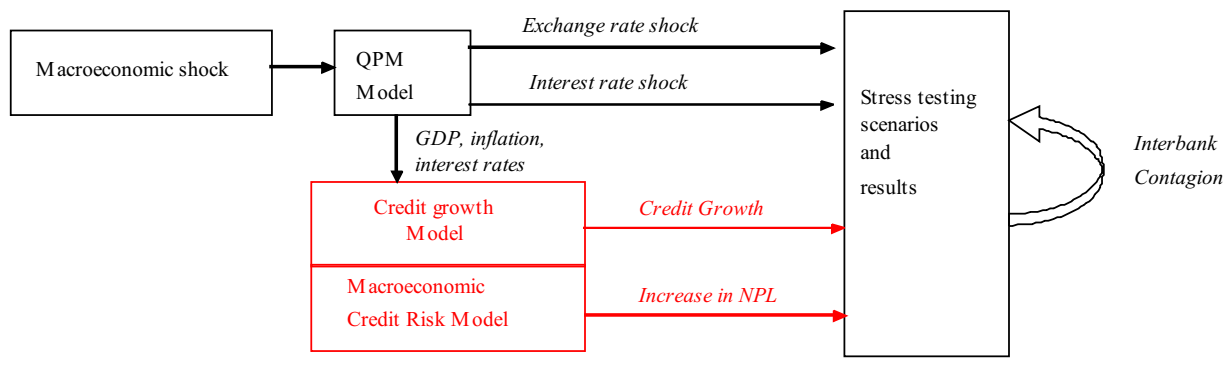

Note: Grey parts of the scheme are newly included or were updated.

QPM (Quarterly Prediction Model) stands for CNB official macroeconomic forecast.

Stress test exercise is a popular method used by many central banks for the purpose of financial stability. The survey of the stress testing employed by the central banks in Central and Eastern European countries can be found e.g. in Boss, Krenn, Puhr, Schwaiger (2007). There are many papers dealing with credit risk modelling issue from the central bank point of view. Financial stability issues related to macroeconomic credit risk modelling in eurozone is discussed e.g. by ECB (2007). Sorge, Virolainen (2006) illustrate the main analytical approaches to macro stress test in the literature and estimate macroeconomic credit risk models for stress test purposes using data for Finland. Wagner, Marsh (2006) study the credit risk transfer in the economy with endogenous financing. They find the transfer of credit risk from banks to non-banks to be more beneficial than credit risk transfer within bank sector.

The article looks first at credit growth modelling (Section 2) and the extension of the credit risk model (Section 3). In Section 4, these models are used to calculate the effects of shocks in a stress testing exercise. Sections 4.1 and 4.2 update the basic historical scenarios from the past, including simple sensitivity tests of credit risk broken down by sector. In 
Section 4.3, the models of credit growth and credit risk are used to abstract from other types of risks (interest rate risk, exchange rate risk, interbank contagion). Section 4.4 presents a complete set of stress tests, while maintaining the link to the CNB's quarterly macroeconomic forecast. This section considers credit risk in relation to other commonly analysed risks. The last section sums up the results and assesses the potential risks for the banking sector.

\section{Credit Growth Modelling}

The strong credit growth observed in recent years calls for the inclusion of a credit growth model, given the one-year horizon of the stress tests. This extension of the stress tests affords a more realistic view of banks' loan portfolios.

The models used most frequently for the loan portfolio growth rate, which are based on panel regressions, were applied to the countries of Central and Eastern Europe, e.g. by Cottarelli, Dell'Ariccia, Vladkova and Hollar (2003) and Duenwald, Gueorguiev, Schaechter (2005). However, the vector error correction (VEC) models are used both for estimates for individual countries and for aggregate data for several countries $-e . g$. Hofmann (2001) and Schadler, Murgasova, Elkan (2005) - we applied it only for the Czech economy. It captures the long-term and short-term relationships between the observed variables. The model does not explicitly address the causality of the observed variables. It is estimated as a system of equations, where each variable is both explanatory and dependent. Where the motivation is to obtain a direct estimate of one of the variables, a single-equation version of the model is used.

In many studies the volume of loans in the economy is expressed as a ratio of loans to the private sector to GDP and is often estimated on the basis of a set of macroeconomic variables. Other studies try to model directly the rate of growth of the absolute volume of loans in the economy, which is considered an important indicator for the assessment of financial stability. Growth in the absolute volume of loans for the countries of Central and Eastern Europe is modelled, for instance by Fabrizio, Igan, Mody, Tamirisa (2006).

As regards the long-term credit growth model, the variables used most frequently in the literature are GDP growth, interest rates and inflation rate. Variables, such as the property price index and the trade balance are also often considered, as well as number of qualitative variables, such as the maturity of the banking sector, the characteristics of the legal environment, the quality of accounting standards, etc. The estimate of the long-term relationship is used to find the equilibrium level of credit growth. Under the standard methodology this long-term relationship is estimated by cointegration analysis. ${ }^{1}$ If the current value is higher, "error correction" occurs, i.e. the value should decline in the future period, and vice versa. In this article we seek the equilibrium level of real credit growth in the economy, taking into account both the demand and supply sides of the credit market. Indicators on the demand side include, for instance, GDP growth and the current level and expected evolution of interest rates. The banks' loan supply depends on variables, such as loan portfolio quality, as measured by the default rate or the distance to default ${ }^{2}$, the interest rate margin or the cost-revenue ratio.

1 The cointegration relationship in the VEC model can be tested, for example, by using the Johansen cointegration test.

2 The distance to default expresses the likelihood of the value of the assets being lower that that of the debt. 


\subsection{The Credit Growth Model Estimated}

The vector error correction (VEC) model was used to estimate real growth in bank loans granted to residents. Nominal credit growth was deflated by the consumer price index (CPI) in the calculation of real credit growth. Quarterly time series of loans and other macroeconomic variables from 1997 Q1 to 2006 Q3 were used to estimate the VEC model.

A number of macroeconomic variables, such as the output gap, the interest rate gap, the unemployment rate, the share of non-performing loans in the total loan portfolio, the real interest rates, the real output growth rate, the inflation rate, growth in real investment and consumption, the exchange rate, the differential between long-term and short-term interest rates, the level of privatisation of the banking sector, etc. were taken into account in the estimate for the Czech Republic. Credit growth should be positively influenced by the real growth of economy as well as growth in real investment and consumption. The growth of economy increases profitability of the firms and enables them to expand their production capacities. For this reason they need more financial sources in order to invest and they demand more credits. Firms also demand more labour and therefore unemployment decreases and households' income is rising. It shifts up household budget constrain as households are getting richer and consequently they demand more credits. Contrary, increase in the real interest rates in economy negatively influences domestic credit growth. Higher real interest rates mean more expensive external financial sources for the corporate and households sector. Hence firms and households demand less credits. Unfavourable economic condition can cause increase in the aggregate default rate in economy. Higher share of non-performing loans on banks' book reduces credit supply. Therefore credit growth should depend negatively on default rate as well as the share of non-performing loans in the total loan portfolio. Positive effect on credit growth has also privatisation of the banking sector related to improvement of the bank management.

First, stationarity of time series was tested. All the time series under consideration were integrated order one - I (1). However, a long-term relationship could not be proved for some of them. In some cases, the signs of the estimated variables were not in line with the economic theory, probably due to the transformation changes that occurred in the Czech economy or due to rather specific events on the credit market. In the end, the long-term real credit growth rate was explained by means of the real GDP growth rate and the default rate of the aggregate credit portfolio of banks. ${ }^{3}$ As the current default rate affects bank's future decisions, we worked with the time series of the default rate lagged by two quarters. The cointegration relationship between the credit growth rate, the real output growth rate and the default rate was significant at the $1 \%$ significance level. Although the cointegration relationship was highly significant, a change in the time series length changed the significance. The instability of this relationship over time corresponds to a number of specific features of the Czech transforming economy. Based on the results achieved, we considered the credit growth rate as a positive function of real GDP and a negative function of the default rate in the economy.

In addition, when choosing the explanatory variables we took into account their possible use for the forecast and hence also the link to the CNB's quarterly macroecono-

3 The literature also uses the distance to default as one of the determinants of credit growth. See, for example, Fabrizio, Igan, Mody and Tamirisa (2006). 
mic forecast. As the model was to be incorporated into the stress testing of the banking sector, an appropriate response of the model to adverse economic developments was also highly desirable. The following VEC credit growth model was chosen with regard to these objectives and econometric properties, only variables whose coefficients were statistically significant in the estimate are included in equation (1).

$$
\begin{gathered}
\Delta \text { loanstr }_{t}=\delta\left(\alpha+\text { loanstr }_{t-1}+\beta_{1} r g d p r_{t-1}+\beta_{2} d f_{t-3}\right)+ \\
+\gamma_{1} \Delta \text { rnewgap }_{t-3}+\gamma_{2} \Delta r g d p r_{t-1}+\gamma_{3} d u m,
\end{gathered}
$$

where loanstr is real credit growth, $r g d p r$ the annual real GDP growth rate, $d f$ the aggregate annual default rate in the economy ${ }^{4}$, rnewgap the interest rate gap on new loans ${ }^{5}$ and dum a dummy variable taking the value of 1 for the period of massive clean-up of banks' loan portfolios. A lag of two quarters was applied to the interest rate gap time series, as it usually takes some time before a change in rates in the economy passes through to the credit demand and supply sides. Forecasts for all the variables used, excluding the default rate, can be obtained from the CNB's quarterly macroeconomic forecast. The macroeconomic credit risk model for the aggregate economy expressed by equation (2) can be used for the default rate. Due to nonlinearity of the model, standard methodology for quality measurement of estimate cannot be applied. Nevertheless, a number of the less common indicators can be used. Estrela's pseudo coefficient of determination is reported in the Table 1. A full description of the macroeconomic credit risk model used for the purposes of stress testing in the CNB can be found in Jakubík (2007). In this paper we use this estimation which was done in 2006 in order to run credit growth model (1).

$$
d f_{t}=\psi\left(-2.0731-4.9947 g d p_{t}+2.7839 R_{t-4}-2.4364 \pi_{t-2}\right)
$$

The default rate is expressed as a standard normal distribution function of a linear combination of non-lagged annual real GDP growth rate $(g d p)$, nominal 1Y Pribor lagged by fours quarters represents nominal interest rate $(R)$ and annual rate of growth of the average quarterly consumer price index lagged by two quarters $(\pi)$ represents inflation. This implies in line with the economic theory a negative dependence of the default rate on GDP and a positive one on real interest rates. The growth of the economy increases demand for the firms' products and their sales are rising. Consequently their profitability increases and they are less vulnerable to fall into default. The opposite effect on default risk of the corporate sector has an increase of interest rate. The companies' debt burden increases and the firms' default risk is rising. Although permanent inflation has harmful impact on the economy, it decreases the real value of debt in the short-run and default probability declines.

4 The annual default rate is the number of new defaulters over a one year reference period as a proportion of the total number of entities existing in that period. The default rate can also be defined analogously in terms of volume based on the obligations assumed by debtors. The second approach was applied. Aggregate default rate expresses default rate based on the all debtors in the economy.

5 The interest rate gap is defined as the difference between real and equilibrium interest rates. The interest rate gap forms part of the CNB's quarterly macroeconomic forecast - see CNB (2003). 
Table 1

Macroeconomic Credit Risk Model (2) of the Czech Economy

\begin{tabular}{|l|c|c|c|c|c|}
\hline Variable & Denoted by & Coefficient & Standard error & t-statistic & $\operatorname{Pr}<|t|$ \\
\hline Constant & $c$ & -2.0731 & 0.1019 & -20.344455 & $<0.0001$ \\
\hline $\begin{array}{l}\text { Gross domestic } \\
\text { product }\end{array}$ & $g d p$ & -4.9947 & 1.9613 & -2.5466272 & 0.0162 \\
\hline $\begin{array}{l}\text { Nominal interest } \\
\text { rate }\end{array}$ & $R_{t-4}$ & 2.7839 & 0.9076 & 3.0673204 & 0.0045 \\
\hline Inflation & $\pi_{t-2}$ & -2.4364 & 1.0994 & -2.2161179 & 0.0344 \\
\hline Estrela's pseudo R & \multicolumn{5}{|c|}{0.970} \\
\hline
\end{tabular}

Equations (1) and (2) can be used to obtain a forecast for the loan portfolio growth rate. Incorporating this forecast into the stress testing can reduce its stationarity. Tables show the results of the estimated model (1). The coefficient of determination of the error correction model (1) was 78\%, while the adjusted coefficient of determination was $76 \%$. The good statistical properties of the model are confirmed by the Durbin-Watson statistic, which was 1.98 .

Table 2

Error Correction Model for Credit Growth

\begin{tabular}{|l|c|c|c|c|}
\hline Variable & Coefficient & Standard error & t-statistic & $\operatorname{Pr}<t \mid$ \\
\hline $\begin{array}{l}\text { Cointegration long-term } \\
\text { relationship }(\delta)\end{array}$ & -0.268 & 0.053 & -5.047 & $<0.0001$ \\
\hline $\begin{array}{l}\text { Difference in interest } \\
\text { rate gap of new loans } \\
\left(\gamma_{1}\right) \text { - } \delta \text { rnewgapt-3 }\end{array}$ & -1.381 & 0.317 & -4.353 & 0.0001 \\
\hline $\begin{array}{l}\text { Difference in real GDP } \\
\text { growth }\left(\gamma_{2}\right)-\Delta r g d p r_{t-1}\end{array}$ & 2.618 & 0.817 & 3.205 & 0.0031 \\
\hline Dummy $\left(\gamma_{3}\right)-d u m$ & 0.029 & 0.009 & -3.381 & 0.0020 \\
\hline R-squared & & 0.780 & 0.758 \\
\hline Adjusted R-squared & \multicolumn{5}{|l}{} \\
\hline
\end{tabular}

Table 3

Estimate of Cointegration Relationship

\begin{tabular}{|l|c|c|c|}
\hline Variable & Standardized coefficient & Standard error & t-statistic \\
\hline Real credit growth - loanstr $_{t}$ & 1.000 & & \\
\hline Real GDP growth $\left(\beta_{t}\right)-r g d p r_{t}$ & -3.639 & 0.609 & -5.973 \\
\hline Aggregate default rate $\left(\beta_{2}\right)-d f_{t-2}$ & 3.647 & 1.327 & 2.749 \\
\hline Constant & 0.047 & & \\
\hline
\end{tabular}

\subsection{The Use of the Credit Growth Model for the Forecast}

Equation (2) implies that we must have forecasts of the nominal interest rate and inflation in order to be able to estimate the model. Forecasts for loans to corporations and households were derived from the forecast for aggregate credit growth. The share of loans to households in the total portfolio was modelled using a simple linear regression equation estimated for the time series in 2003-2006. This was used to obtain a forecast for the no- 
minal volume of loans to households. ${ }^{6}$ The volume of loans to corporations was then estimated as a residual. Figure 1 shows the evolution of nominal annual credit growth, including a forecast for 2007 obtained using equation (1).

Figure 1

Nominal Annual Credit Growth (\%)

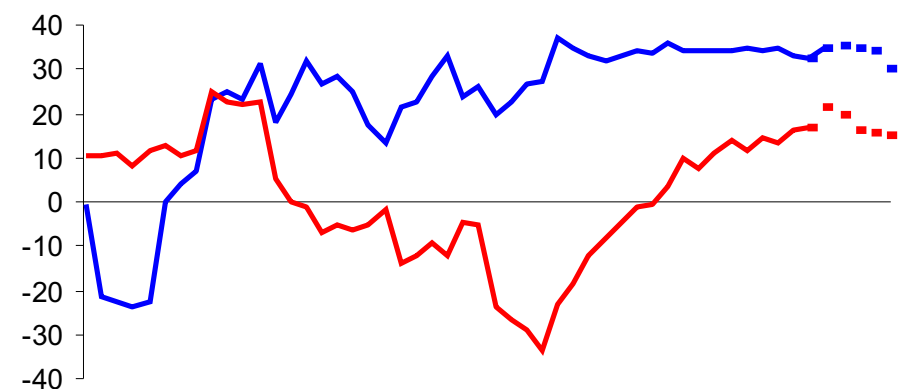

$\begin{array}{lllllllllllll}95 & 96 & 97 & 98 & 99 & 00 & 01 & 02 & 03 & 04 & 05 & 06 & 07\end{array}$

Nominal credit growth to corporate sector

Source: CNB

Nominal credit growth to households

Note: 2007 data denote prediction

Based on the estimate of the future evolution of macroeconomic variables and equations (1) and (2), the second half of 2007 should see some easing in real credit growth owing to a falling GDP growth rate and a widening positive interest rate gap. When interpreting the results, one should keep in mind that there is some uncertainty surrounding not only the estimate of the model (1), but also the forecasts of the key macroeconomic variables. The considerable instability of long-term relationships over time and the numerous specific features of a transforming economy are a general problem of credit growth modelling in the Czech Republic.

\section{Credit Risk Models}

In a stress testing exercise, it is necessary to assess the change in the credit risk of a loan portfolio in relation to the change in the macroeconomic environment. To this end, a macroeconomic credit risk model for the aggregate loan portfolio (see equation (2)) was developed in the CNB in 2006.

One disadvantage of the model (2) is that it cannot capture the different sensitivities of corporations and households to the change in the macroeconomic environment. The structure of the loan portfolio has changed considerably over the past five years. The share of loans to households in banks' total loan portfolio increased from $10 \%$ in 2001 to almost $40 \%$ at the end of 2006. It is thus apparent that the household sector is becoming increasingly significant in the total loan portfolio. For this reason, it would be appropriate to estimate the macroeconomic credit risk model separately for the corporate and house-

6 Throughout this article, the term "households" refers to private individuals excluding sole traders. 
hold sectors. The main obstacle to the estimation of such models is the non-availability of data on the dependent variable.

The aggregate risk model was estimated on quarterly data on inflow of non-performing loans (NPLs). ${ }^{7}$ However, such data is only available on an aggregate basis and cannot be obtained separately for the household and corporate sectors. The sectoral breakdown shows NPL stocks, not flows. To obtain flows, one has to estimate the outflow in NPLs as a result of write-offs, sales or enforcement of such classified liabilities of banks. The following relationship applies to the stock of NPLs, the default rate and the rate of outflow.

$$
N P L_{2}=N P L_{1}-u N P L_{1}+d f\left(\text { Loans }_{1}-N P L_{1}\right),
$$

where $N P L$ is the stock of NPLs in the relevant period, $u$ the rate of outflow, $d f$ the default rate and Loans $_{l}$ loans at the beginning of the period under review. This enables us to derive the following relationship (4) for the default rate.

$$
d f=\frac{\Delta N P L+u N P L}{\operatorname{Lons}_{1}-N P L_{1}}
$$

Depending on the frequencies monitored, equation (4) can be used to compute the quarterly or annual default rate. Except for the rate of outflow, all the variables in relationship (4) are usually known. Volumes of total loans and NPLs are available for the Czech economy broken down by sector. The rate of outflow was only available for aggregate loans. This figure is highly volatile, mainly due to non-recurring massive write-offs at the end of the 1990s and at the beginning of the new millennium as a result of clean-ups of large banks' balance sheets. It can be assumed that most of the problem loans related to corporations rather than households and that the rate of decrease for the household sector is relatively stable over time. The period of write-off, sale or enforcement of NPLs to households was chosen to be two years as an expert estimate. If we work with the annual default rate, the corresponding rate of decrease is $0.5{ }^{8} \mathrm{Based}$ on this assumption, the default rate of households in the economy was derived using relationship (4). If we assume that the aggregate default rate is a weighted average of the default rates for corporations and households, the default rate for corporations can then be derived.

\subsection{The Macroeconomic Credit Risk Model for the Household Sector}

To model the credit risk for the household sector the same methodology was used as for estimating the aggregate model expressed by equation (2). ${ }^{9}$ The resulting model was estimated for the annual default rate time series from 1996 Q3 to 2006 Q3. The quarterly

7 NPLs are loans with a classification of 3 or higher, i.e. substandard, loss and doubtful.

8 Parameter $u$ in the equation (4) may not in fact be constant over time. Nonetheless, we believe that the level of 0.5 is relatively realistic and consistent with anecdotal evidence.

9 The estimate is based on a one-factor latent model. This methodology can be found, for instance, in Jakubík (2007). 
time series of the annual default rate was generated from the monthly series of the annual default rate calculated using relationship (4) by averaging the three monthly figures corresponding to the relevant quarter. Although the default rate obtained using equation (4) was available from 1994, the time series on which the model was estimated had to be shortened as a result of some lags in the model and due to the shorter series of the other macroeconomic indicators included in the model.

The ability of the households to meet their financial obligation depends mainly on the income to instalment ratio. The households usually have a regular income as a salary, pension or some kind of rent. Besides that, they can own financial assets, real or personal estates. If their disposable income decreases under the certain threshold, they have to sell owned assets. If they already have nothing to sell they fall into default. One of the key macroeconomic determinants for the households default is unemployment rate which significantly affects the households' income. In the case that the key breadwinner of the heavy indebted household is fired from the job the household is usually not able to compensate his/her income and falls into default under the condition that all owned assets are already sold. Instalment of the debt depends on the interest rates in the economy. Default probability of the indebted household increases with increase of the interest rate under circumstances that interest rate for the loan is not fixed. Besides the indicators influencing the income to instalment ratio, principal of the debt can be also affected. Increase in the price level declines the real value of the debt. Hence, the inflation decreases the default probability of the households.

A whole range of macroeconomic indicators were considered for the estimate. The model chosen as the statistically best model, in line with the economic theory, was one containing the unemployment rate and the real interest rate. The real interest rate was calculated by deflating the annual PRIBOR by the CPI. The statistically best results were achieved with a lag in the real interest rate of three quarters. This result expresses the lagged impact of an interest rate change on debtors resulting from interest rate fixation. The unemployment rate was lagged by four periods, which corresponds to the lagged impact on payment discipline in the event of loss of employment. ${ }^{10}$ Also considered for the estimation of the model were the nominal interest rates, the inflation, the interest rate gap, the real GDP growth rate, the output gap, the ratio of interest paid to income or disposable income, etc. Disposable income was modelled using average wages and household consumption, while interest paid was modelled as the product of the credit volume and the annual PRIBOR increased by a certain interest rate spread. The resulting estimated model corresponds to equation (5). In the same way as model (2), standard methodology for quality measurement of estimate cannot be applied due to nonlinearity. Nevertheless, the estimate of the coefficients and Estrela's pseudo coefficient of determination is reported in the Table 4.

$$
d f_{t}=\psi\left(c+\beta_{1} u_{t-4}+\beta_{2} r_{t-3}\right)
$$

10 The loan is initially repaid from savings or the redundancy payment; payment discipline is affected only after that. 
Table 4

Default Rate Model for the Household Sector

\begin{tabular}{|l|c|c|c|c|c|}
\hline $\begin{array}{l}\text { Description of variable } \\
\text { corresponding to estimated } \\
\text { coefficient }\end{array}$ & Notation & Estimate & Standard error & t-statistic & $\operatorname{Pr}<|t|$ \\
\hline Constant & $c$ & -2.142 & 0.048 & -44.941 & $<0.0001$ \\
\hline Unemployment $\left(\beta_{l}\right)$ & $u_{t-4}$ & 2.956 & 0.563 & 5.249 & $<0.0001$ \\
\hline Real interest rate $\left(\beta_{\nu}\right)$ & $r_{t-3}$ & 1.204 & 0.522 & 2.308 & 0.0262 \\
\hline Estrela's pseudo R & \multicolumn{5}{|l}{0.380} \\
\hline
\end{tabular}

\subsection{The Model for the Corporate Sector}

The estimate of the macroeconomic model for the corporate sector is not yet available. Unlike in the household sector, the outflow of the non-performing loans from the banks' balance sheets is not easy to estimate. A historical time series of the default rate is lacking for the estimate of the model. This could be resolved in the future by the Central Register of Credits operated by the Czech National Bank, since October 2002. The register contains data on legal entities and individual entrepreneurs and can be used to obtain information on the payment discipline of banks' clients. However, this data is currently of no use for credit modelling due to short time series. In the end, the default rate for the corporate sector was estimated as a weighted difference between the default rates for the aggregate economy and the household sector. The aggregate default rate was considered as a weighted average of the default rates for corporations and households. The weights were derived from the shares of the credit volume for the individual sectors in the total loan portfolio.

\subsection{The Forecast for Credit Risk of Households}

The CNB's quarterly macroeconomic forecast for the unemployment rate, the 12-month PRIBOR and the CPI can be used to predict credit risk in the household sector.

Figure 2

Default Rate for the Household Sector (\%)

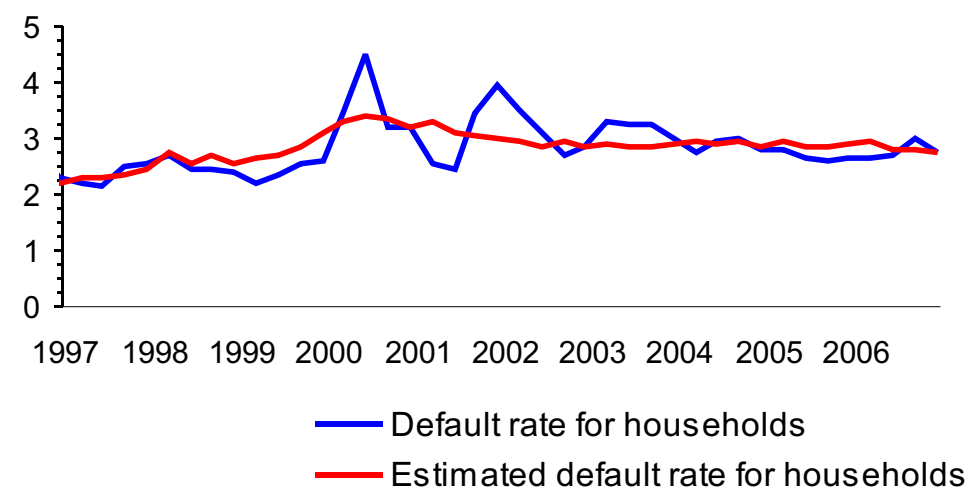

Source: CNB 


\section{Use of the Models and Stress Testing Results}

\subsection{Basic Stress Tests with Historical Scenarios}

In the stress testing exercise we first consider basic tests based on a methodology of two scenarios (Scenario I and Scenario II) representing two different types of stress in banks' portfolios. The values of the parameters in each scenario are identical to those used in previous Financial Stability Reports. Scenario I consists in the combination of a hypothetical increase in interest rates of 1 percentage point, a depreciation of the exchange rate of $15 \%$ and an increase in the share of non-performing loans (NPLs) of $30 \%$ by reclassification of loans. Scenario II uses the combination of an increase in interest rates of 2 percentage points, a depreciation of $20 \%$ and an increase in the share of NPLs in total loans of 3 percentage points (a detailed description of these scenarios can be found in CNB (2006)). These scenarios take into account the prevailing international practice and the specific conditions of the Czech economy. The selected parameters reflect the historical experience from the currency crisis and subsequent recession in 1997-1999.

The tests demonstrate the evolution of capital adequacy and the resilience of banks' portfolios to extreme shocks in the long term. The test results are comparable over the period 2000-2006. The stress tests are based on the bottom-up methodology - they use financial data for individual banks and subsequently aggregate them for the banking sector as a whole.

The impacts of the two scenarios are assessed by comparing the capital adequacy ratio $(\mathrm{CAR})^{11}$ before the hypothetical shocks and after the impact of these shocks on the banks' portfolios (the post-test CAR, see Figure 3).

Figure 3

Results of Stress Test Scenarios for the Czech Banking Sector (capital adequacy; \%)

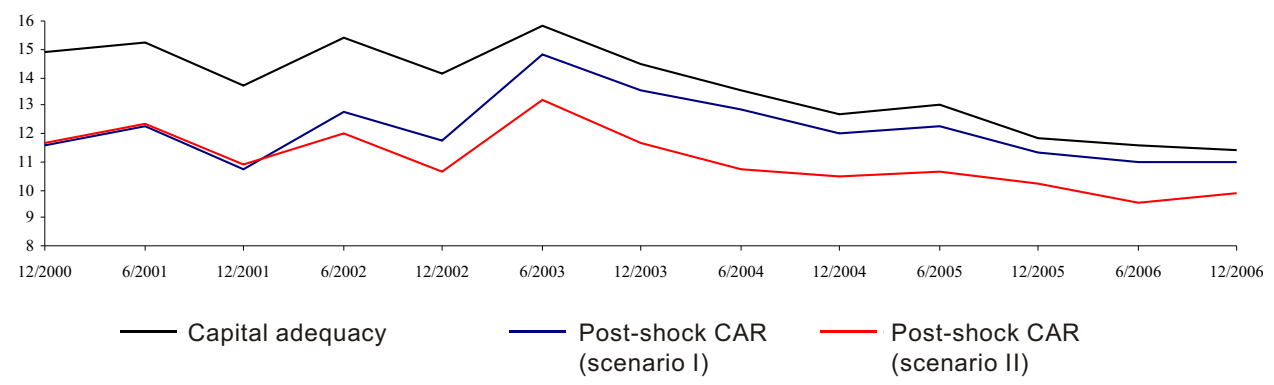

Source: CNB

Note: The scenarios differ due to the fact that they use different methodologies for the growth in non-performing loans (NPLs), hence the resulting CAR for each scenario develops differently over the monitored time horizon. The results exclude the effect of interbank contagion.

11 That is, the current CAR measured as the ratio of capital to risk-weighted assets of the banking sector. 
Capital adequacy declined by 3.5 percentage points in 2000-2006. This decline reflects the fact that some banks used their profits for the payment of dividends. In addition, risk-weighted assets recorded an increase. In the same period, the post-shock CAR decreased by just 0.6 percentage point for Scenario I and 1.8 percentage points for Scenario II. The impacts of both shock scenarios thus decrease over time, which suggests a decrease in the exposure of the banking sector to basic types of risk. The post-shock CAR complied with the required $8 \%$ regulatory minimum for both scenarios. However, some banks could be below the required minimum and would need a capital injection to return to this threshold. For these banks, the effects of adverse changes would have a negative impact on the payment of dividends and bonuses. Overall, the banking sector proved resilient to the extreme stress of the shocks based on historical scenarios.

\subsection{Simple Credit Risk Sensitivity Tests}

The modelling of credit growth and credit risk for the household and non-financial corporation sectors (Section 4.3) was preceded by simple sensitivity tests on portfolios of loans granted by banks. These tests used credit shocks based on the hypothesis of conversion of a certain volume of consumer credit and housing loans into NPLs, which corresponds to an increase in credit risk vis- $\grave{a}$-vis households (private individuals). The hypothesis of conversion of a certain volume of loans into NPLs was tested in the same way in the non-financial corporations sector (see Figure 4 and Figure 5).

\section{Figure 4}

Results of Tests with Credit Risk Scenarios for Households, 2006 (capital adequacy; \%)

Source: CNB

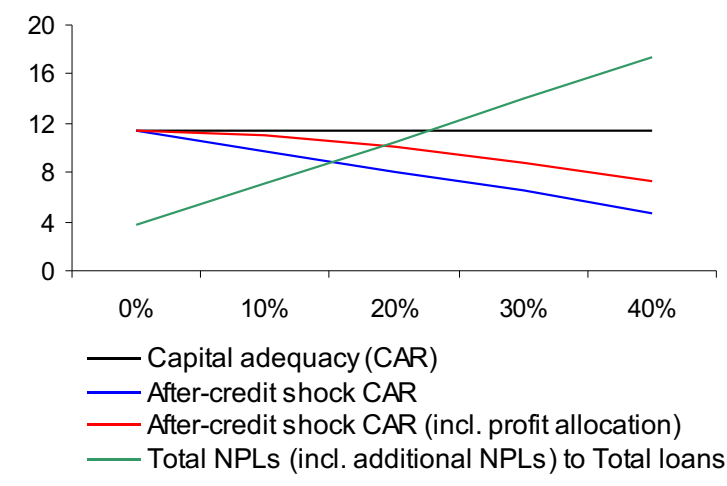

Note: Five scenarios of additional NPLs as $0-40 \%$ of consumer and housing loans becoming to non-performing loans.

The simple sensitivity tests capture the effects of the one-off conversion of $10-40 \%$ of total loans in the given sector into NPLs. The tests analyse the tolerability of such shocks in banks' portfolios and in aggregated form for the banking sector as a whole. The shocks imply additional growth in NPLs, which generates an additional need for capital to cover the credit risk. The tests assume that the banks will create provisions equally for both existing and additional NPLs. The impact of the type and amount of collateral is not taken into account separately in the tests. 
Figure 5

Results of Tests with Credit Risk Scenarios for Non-financial Corporations, 2006

(capital adequacy; \%)

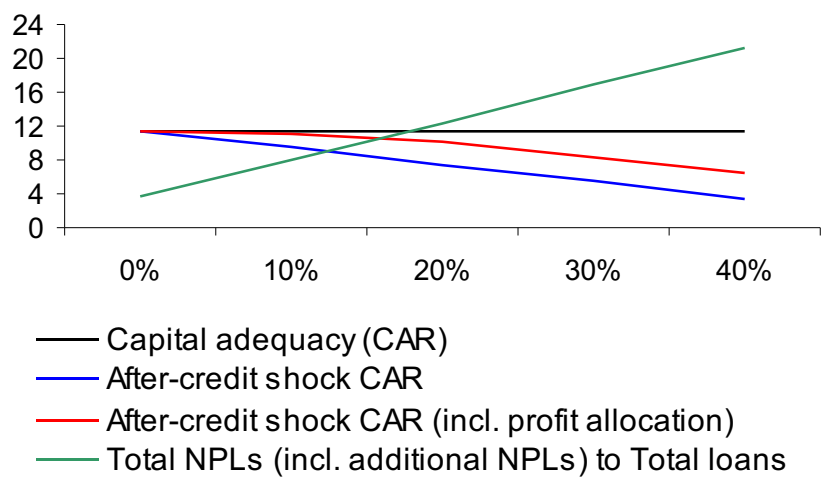

Source: CNB

Note: Five scenarios of additional NPLs as $0-40 \%$ of non-financial corporation loans becoming to non-performing loans.

Banks are able to withstand the simple credit shock which was tested for the individual sectors. In the case of an isolated shock to the household sector only, the banking sector was able to withstand ${ }^{12}$ the conversion of up to $35 \%$ of existing loans into NPLs. The analogous figure for the corporate sector was 30\%. The results correspond to the larger volume of loans and risk undertaken in the corporate sector. As for the total loan portfolio, banks would be able to withstand the risk of the conversion of around $16 \%$ of loans into NPLs. The expected further growth in loans to households and corporations presents a potential accumulated risk of subsequent loan defaults in the two sectors.

\subsection{Credit Risk Tests Using Credit Growth Models}

The following tests examine the effects of a credit shock separately for the household sector and the non-financial corporations sector. Other types of shocks (interest rate shock, exchange rate shock, interbank contagion) are not taken into account. The models of credit growth and credit risk as described in Sections 2 and 3 are used for this purpose. The credit shock is based on the assumption that at the one-year horizon banks will hold a quantity of NPLs dating from the previous period and that a proportion of the loans will be converted into NPLs at the same time. The new growth in NPLs was estimated from the credit risk model and the CNB's quarterly macroeconomic forecast for the following year. Estimated credit growth is also taken into account for the calculation. The tests assume that banks will create provisions equally for both existing and additional NPLs, and collateral is not taken into account.

The tests were based on the forecast of the annual credit growth rate for 2007 , amounting to $30 \%$ for households, $15.5 \%$ for corporations and $16 \%$ for total loans for the banking sector. The scenarios (for loans to households and corporations, and total loans) tested the credit risk forecasts in the form of shocks for the 2007 horizon.

12 That is, the post-test CAR was maintained above $8 \%$. 


\section{Figure 6}

Results of Stress Tests with Incorporation of Credit Growth and Credit Risk Models (capital adequacy)

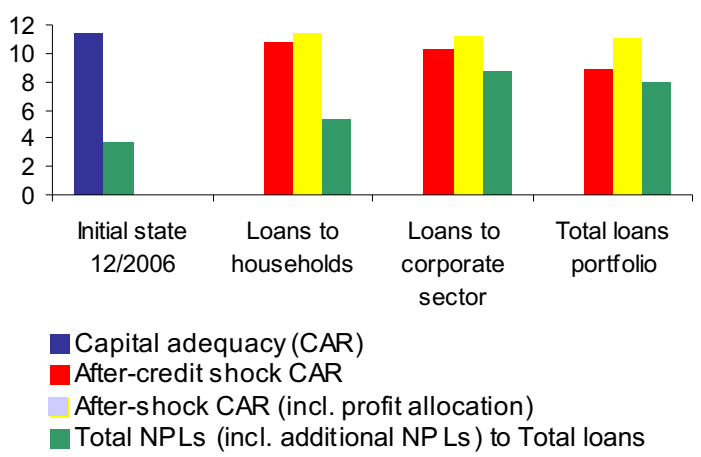

Source: CNB

Note: Figure shows results of the sole credit risk shock, firstly for the loans to households, secondly for the loans to corporate sector and finally for the total loans portfolio. The other types of shocks are not considered. Scenarios of additional NPLs shocks and credit growth of loans in 2007.

The effect of the credit shock on capital for the household sector was relatively small (see Figure 6). The impact on the corporate sector would be higher, but still tolerable (10.3\% CAR). The credit shock considered for all loan portfolios of the banking sector would result in an $8 \%$ share of NPLs in total loans in the banking sector, while the CAR would probably be $11 \%$.

\subsection{Macro Stress Test with Consistent Model Scenarios}

This section follows up on the methodology of scenarios derived from macroeconomic models presented in the Financial Stability Report 2005. The macro stress tests are based on forecasts for macroeconomic variables obtained from the CNB's quarterly forecast, which are then used in macroeconomic models of credit growth and credit risk (see Sections 2 and 3). Unlike in the Financial Stability Report 2005, credit risk is thus tested on separate portfolios for households and non-financial corporations, with credit growth forecasts also being newly added for the two sectors.

The baseline model scenario uses the CNB's quarterly macroeconomic forecast of April 2007, which estimates the developments in the Czech economy in 2007 and 2008. Besides the baseline model scenario, three alternative scenarios (A, B and C) were applied which reflect less probable shocks. The shocks in these scenarios take into consideration the history of real economic growth and its links to other macroeconomic variables. The parameters of these scenarios are identical to those in the scenarios included in the Financial Stability Report 2005 in order to preserve the comparability of the tests over time. The differences between the alternative scenarios and the baseline scenario reflect different hypotheses and shocks for the individual scenarios; the aforementioned period is relevant for the choice of the parameters tested (see Table 5). 
Table 5

Differences between the Alternative Scenarios and the Baseline Scenario

\begin{tabular}{|l|c|c|c|c|}
\hline Type of scenario & period & Scenario A & Scenario B & Scenario C \\
\hline Real GDP growth (\% y-o-y) & 4Q 2007 & -1.0 & -1.0 & -3.1 \\
\hline Inflation rate - CPI (\% y-o-y) & 4Q 2007 & 0.4 & -0.3 & -0.7 \\
\hline Nominal growth of loans (\%) & 4Q 2007 & -2.0 & -3.3 & -10.3 \\
\hline Interest rate (percentage points) & 2Q 2007 & 0.8 & -0.6 & -0.7 \\
\hline Exchange rate (percentage points) & 2Q 2007 & 3.2 & -5.4 & 1.8 \\
\hline
\end{tabular}

\section{Baseline Scenario}

The baseline scenario is derived from the CNB's April 2007 forecast,${ }^{13}$ which expects real GDP growth of 5.7\% in 2007 and 5.3\% in 2008. The baseline scenario does not contain any risks that would pose an immediate threat to the stability of the banking sector. Inflation will be below 3.6\% in the end of 2007 and decrease slightly to 3.3\% in 2008 . Consistent with the forecast is a gradual rise in interest rates. Relatively low interest rates, the positive outlook for investment activity and GDP growth will boost growth in lending to households and corporations. The low interest rate differential will prevent growth in debt in foreign currencies.

\section{Alternative Scenario A}

Alternative scenario A analyses the potential response of the domestic economy to a significant global negative demand shock. Such a shock is not very likely, but it might hypothetically occur in a situation where global imbalances associated with a loss of confidence in the main economic zones suddenly correct and interest rates of the main world currencies, i.e. the dollar and the euro, start to rise. GDP growth rates in 2007 and 2008 would be about 1 percentage points lower than in the case of the baseline scenario, and interest rates would be higher.

\section{Alternative Scenario B}

Alternative scenario B combines the effects of the development of the nominal exchange rate and the development of inflation. The scenario assumes a sudden appreciation of the exchange rate and a negative supply shock, which would, ceteris paribus, result in a rise in inflation. Overall, however, the stronger exchange rate would cause a fall in GDP growth and a slight decline in inflation compared to the baseline scenario. The monetary policy response would be to cut interest rates.

13 A detailed description of the CNB macroeconomic forecast is given in CNB Inflation Report (2007), available from www.cnb.cz. 


\section{Alternative Scenario C}

Alternative scenario $\mathrm{C}$ reflects the risks associated with a possible drop in domestic demand and assumes a gradual decline in GDP growth between 2007 Q2 and 2008 Q1. A negative shock to GDP growth would cause the output gap to widen and inflation to fall. Simultaneously, the credit growth would be reduced in comparison to baseline scenario. The monetary policy response would be a significant easing, which would help to revive economic activity, in particular in 2008. The lower interest rates compared with other countries would also foster a slight depreciation of the exchange rate, which, in turn, would further ease the monetary conditions.

\section{Test Results for the Model Scenarios}

The capital adequacy ratio in the baseline scenario would be $11.1 \%$ in 2007 (on December 2006 banking sector data and the volume of loans modelled). The share of new NPLs in the volume of claims modelled would be $4 \%$. The capital adequacy ratio would be 0.6 percentage points lower in Scenario A, at the same level in Scenario B and Scenario C than in the baseline scenario for 2007. The new NPLs of the banking sector would be $4.3 \%, 4.2 \%$ and $4.9 \%$ in scenarios A, B and C respectively at the one-year horizon (see Figure 7).

\section{Figure 7}

Results of Scenarios of Macro Stress Testing (\%)

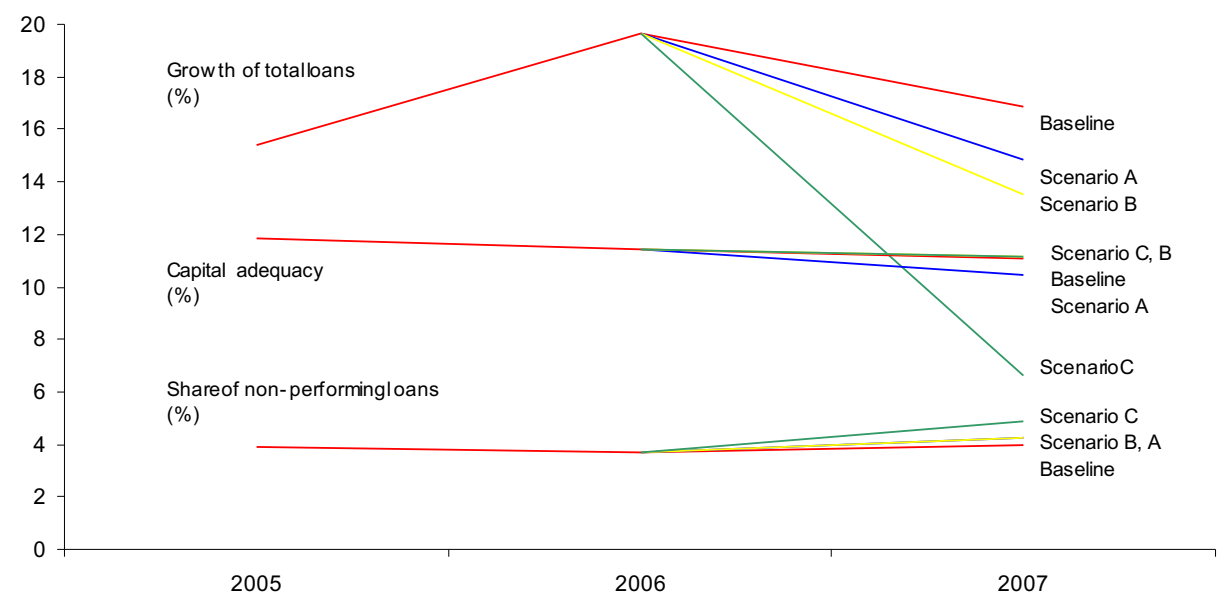

Source: CNB

Note: Growth in total loans is defined as an average annual rate of growth. The share of new non-performing loans (NPLs) is related to the estimation of the loan volume at the end of 2007.

The results for the model scenarios are contained in the joint summary of the stress test results for the banking sector together with the historical scenarios (see Table 6). The banking sector as a whole seems to be resilient to the effects of the macroeconomic tests under consideration, including the alternative credit risk tests. The banking sector displays an ability to withstand shocks corresponding to the two scenarios based on historical experience and the scenarios based on the macroeconomic model. 
Table 6

Summary of Results of Stress Tests for the Banking Sector (data in \% unless stated otherwise)

\begin{tabular}{|l|c|c|c|c|c|c|c|c|c|}
\hline \multirow{2}{*}{ Scenario type } & \multicolumn{2}{|c|}{ Baseline } & $\begin{array}{c}\text { Scena- } \\
\text { rio A }\end{array}$ & $\begin{array}{c}\text { Scena- } \\
\text { rio B }\end{array}$ & $\begin{array}{c}\text { Scena- } \\
\text { rio C }\end{array}$ & \multicolumn{2}{|c|}{ Scenario I } & \multicolumn{2}{c|}{ Scenario II } \\
\cline { 2 - 10 } & $\mathbf{6 / 2 0 0 6}$ & $\mathbf{2 0 0 6}$ & $\mathbf{2 0 0 6}$ & $\mathbf{2 0 0 6}$ & $\mathbf{2 0 0 6}$ & $\mathbf{6} / 2006$ & $\mathbf{2 0 0 6}$ & $\mathbf{6} / 2006$ & $\mathbf{2 0 0 6}$ \\
\hline Capital adequacy (CAR) 1) & 11.5 & 11.4 & 11.4 & 11.4 & 11.4 & 11.5 & 11.4 & 11.5 & 11.4 \\
\hline Results for the chosen scenario type & -2.3 & -2.4 & -3.7 & -1.9 & -1.5 & -2.3 & -2.0 & -5.2 & -4.9 \\
\hline Overall impact of shocks (percentage points CAR) & 0.0 & 0.0 & -1.2 & 0.9 & 1.0 & -1.6 & -1.5 & -3.3 & -3.0 \\
\hline Interest rate shock & 0.0 & 0.0 & 0.3 & -0.4 & 0.1 & 1.1 & 1.2 & 1.5 & 1.7 \\
\hline Exchange rate shock & -2.2 & -2.1 & -2.5 & -2.2 & -2.5 & -1.6 & -1.5 & -3.0 & -2.7 \\
\hline Credit shock & - & -0.6 & -0.6 & -0.6 & -0.5 & - & - & - & - \\
\hline$\ldots$ households & - & -1.5 & -1.6 & -1.6 & -1.8 & - & - & - & - \\
\hline$\ldots$ non-financial corporations & 0.0 & 0.0 & -0.2 & 0.0 & -0.1 & -1.1 & -1.0 & -1.4 & -1.3 \\
\hline$\ldots$ indirect impact of exchange rate shock & -0.1 & -0.2 & -0.3 & -0.2 & -0.2 & -0.1 & -0.2 & -0.4 & -0.8 \\
\hline Interbank contagion 2) & 2.0 & 2.0 & 2.7 & 1.7 & 1.2 & 1.7 & 1.5 & 2.9 & 2.9 \\
\hline Profit allocation (percentage points CAR) 3) & 11.2 & 11.1 & 10.5 & 11.1 & 11.1 & 10.9 & 10.9 & 9.2 & 9.4 \\
\hline After-shock CAR & 0.0 & 0.1 & 0.2 & 0.1 & 0.1 & 0.1 & 0.1 & 0.6 & 0.6 \\
\hline Capital injection (percentage of GDP) 4) & -62.9 & -74.3 & -100.0 & -60.8 & -42.6 & -68.6 & -65.5 & -100.0 & -100.0 \\
\hline Share of banks with negative capital after shock 5) & 0.0 & 0.0 & 0.2 & 0.0 & 0.0 & 1.2 & 1.3 & 5.1 & 11.3 \\
\hline Impact on dividends and royalties 6) & & &
\end{tabular}

Notes:

1) CAR means the capital adequacy ratio defined in accordance with the relevant CNB regulations (in particular those governing the capital adequacy of banks and other prudential business rules).

2) Test integrated with interbank contagion for Method 1, expected level of loss given default (LGD) $100 \%$ and chosen probability of the banks' failure (default) on the basis of the CAR.

3) The scenarios assume that in the absence of shocks each bank would generate profit (or loss) equal to the average for the previous five years and that it would use any profit as a first line of defence against a declining CAR.

4) The capital need to ensure that each bank has a post-shock CAR of at least $8 \%$.

5) Market share of banks with negative capital after the impact of the assumed shocks (as a percentage of total assets).

6) As a percentage of dividends and bonuses of the previous calendar year.

Scenarios: baseline, A, B and C are based on the macroeconomic forecasting model of the Czech National Bank and the credit risk model (see the Financial Stability Report for 2005).

Scenario I and Scenario II are based on the chosen hypothetical and historical shocks (see methodology in the Financial Stability Report for 2004). They differ from results set out in Figure 2 since they include the impact of interbank contagion.

\section{Conclusions}

The stress tests confirmed that the current rapid rise in household indebtedness does not pose any significant risk to the banking sector instability. However, the dynamic growth in loans to households should be viewed in the context of faster growth in lending to corporations, the preponderance of long-term loans and the prevailing low interest rate level. A combination of continuing credit growth and an unexpected increase in interest rates might lead to higher capital requirements and the need to cover a rise in credit risk. High household indebtedness could necessitate higher provisioning in the banking sector if banks misjudge the ability to repay debts and other risks. Presented model-based stress tests pointed out possible need to further increase banks' regulatory capital for more than one-year horizon. 


\section{References}

Boss, M., Krenn, G., Puhr, C., Schwaiger, M. (2007), "Stress Testing the Exposure of Austrian Banks in Central and Eastern Europe". Financial Stability Report 13, Oesterreichische Nationalbank.

Coricelli, F., Masten, I. (2004), "Growth and Volatility in Transition Countries: The Role of Credit". IMF.

Cottarelli, C., Dell'Ariccia, G., Vladkova Hollar, I. (2003), "Early Birds, Late Risers, and Sleeping Beauties: Bank Credit Growth to the Private Sector in Central and Eastern Europe and the Balkans". IMF Working Paper 03/213.

Čihák, M., Heřmánek, J., Hlaváček, M. (2007), "New Approaches to the Stress Testing of the Czech Banking Sector". Czech Journal of Economics and Finance, 57 (1-2), pp. 41-59.

CNB (2003), "The Czech National Bank's Forecasting and Policy Analysis System". Czech National Bank.

CNB (2006), "Financial Stability Report 2005”. Czech National Bank.

CNB (2007), "Inflation Report 2007". Czech National Bank.

Duenwald, C., Gueorguiev, N., Schaechter, A. (2005), "Too Much of a Good Thing? Credit Booms in Transition Economies: The Cases of Bulgaria, Romania, and Ukraine". IMF Working Paper 05/128.

ECB (2007), "Global Macro-Financial Developments and Expected Corporate Sector Default Frequencies in the Euro Area". Financial Stability Review, June, European Central Bank, pp. 152-158.

Fabrizio, S., Igan, D., Mody, A., Tamirisa, N. (2006), "Export Structure and Credit Growth". IMF.

Hofmann, B. (2001), "The Determinants of Private Sector Credit in Industrialised Countries: Do Property Prices Matter?” BIS Working Paper No. 108.

Jakubík, P. (2007), "Macroeconomic Environment and Credit Risk". Czech Journal of Economics and Finance, 57 (1-2), pp. 60-78.

Rösch, D. (2005), "An Empirical Comparison of Default Risk Forecast from Alternative Credit Rating Philosophies". International Journal of Forecasting 21, 21 (1), pp. 37-51.

Schadler, S., Murgasova, Z., Elkan, R. (2005), Credit Booms, Demand Booms, and Euro Adoption: Challenges for Central Banks in an Enlarged EMU. Volume 9, Springer Vienna.

Sorge, M., Virolainen, K. (2006), "A Comparative Analysis of Macro Stress-Testing Methodologies within Application to Finland”. Journal of Financial Stability, 2 (2), pp. 113-151.

Wagner, W., Marsh, I. (2006), "Credit Risk Transfer and Financial Sector Stability”. Journal of Financial Stability, 2, June 2006. 